\title{
An Immunohistochemical Study on the Expression of Sex Steroid Receptors in Canine Mammary Tumors
}

\author{
Leena Rajathy Port Louis, Khub Chandra Varshney, and Madhavan Gopalakrishnan Nair
}

Department of Veterinary Pathology, Rajiv Gandhi College of Veterinary and Animal Sciences, Kurumbapet, Puducherry 605 009, India

Correspondence should be addressed to Khub Chandra Varshney, headpath@yahoo.co.in

Received 30 November 2011; Accepted 4 January 2012

Academic Editors: T. Agui and W. C. Wilson

Copyright ( 52012 Leena Rajathy Port Louis et al. This is an open access article distributed under the Creative Commons Attribution License, which permits unrestricted use, distribution, and reproduction in any medium, provided the original work is properly cited.

\begin{abstract}
Steroid hormones are found to play a major role in the genesis and progression of mammary tumors. The aim of this study was to immunohistochemically detect the presence of estrogen receptor alpha $(\mathrm{ER} \alpha)$, estrogen receptor beta (ER $\beta)$, and progesterone receptor (PR) and also to study the association between these markers in 29 cases of benign (11) and malignant (18) canine mammary tumors. ER $\alpha$ immunostaining was noticed in only one case of carcinosarcoma specifically in the nuclei of epithelial and a few myoepithelial cells. ER $\beta$ immunostaining was noticed in the nuclei and cytoplasm of epithelial cells and smooth muscles lining the blood vessels. Immunoexpression of ER $\beta$ was $82 \%$ in benign tumors and $78 \%$ in malignant tumors. PR immunostaining was expressed in the nuclei of epithelial cells in both benign and malignant tumors. Among the 15 PR+ cases, 6 (55\%) were of benign type, and 9 (50\%) were of malignant type. The most common group of hormone receptor was the ER $\alpha-/ \mathrm{PR}+/ \mathrm{ER} \beta+(46 \%)$ in benign tumors and $\mathrm{ER} \alpha-/ \mathrm{PR}-/ \mathrm{ER} \beta+(38 \%)$ in malignant tumors. Although there was no significant association between ER $\alpha$ and $\mathrm{PR}$ with $\mathrm{ER} \beta$, the findings indicated that $\operatorname{ER} \beta$ was consistently expressed in both benign and malignant tumors, irrespective of $\mathrm{ER} \alpha$ and PR status.
\end{abstract}

\section{Introduction}

Mammary gland tumors are among the most common neoplasms in dogs and have been reported worldwide. The majority of mammary neoplasms in female dogs are of epithelial origin, and approximately $50 \%$ of them are malignant [1]. These neoplasms have a complex morphology in forming epithelial, mixed, and mesenchymal types [2]. Histologic evidence of cancer does not invariably imply a malignant clinical course. Therefore, reliable prognostic factors are of great importance for estimating the individual risk of unfavourable clinical outcome. There are some recognized, well-accepted prognostic factors of malignant mammary neoplasms in the dog, and these include tumor size, lymph node status, histologic type, histologic malignancy grade, degree of nuclear differentiation, and distant metastasis. There are also other proven or controversial host and tumor prognostic factors such as HER-2, p53, PCNA, and $\mathrm{Ki}-67$, and the number of new ones are steadily increasing [3]. Although several studies have been carried out on the prognostic aspects of canine mammary neoplasms, some areas, especially the role of steroid hormone receptors, remain uncertain [4]. The risk of canine mammary neoplasia is affected by exposure to estrogen in early mammary development. The relative risk for mammary neoplasms in female dogs spayed before estrous is $0.5 \%$, after the first cycle $8 \%, 26 \%$ after the second cycle; with the protective effect being lost after about 4 cycles. Inspite of this, there are only limited reports on clinical utilization of proliferation markers and steroid receptors in canine mammary neoplastic conditions [5]. Both estrogen and progesterone are mitogenic by autocrine or paracrine mechanisms. Since steroids regulate the expression of certain cyclins or kinase inhibitors, they may control cell-cycle progression directly [6].

The development of most mammary gland carcinomas is estrogen dependent, and the majority of canine mammary gland carcinomas express estrogen receptors (ERs). Benign tumors and well-differentiated tumors are more likely to be 
ER-positive, whereas undifferentiated, anaplastic tumors are more likely to be ER-negative [4]. Estrogen receptor expression has also been found to be associated with the hormonal status of the dog. Younger, intact dogs were more likely to have ER-positive tumors than older ovario-hysterectomized dogs.

In contrast to the normal breast, most premalignant breast lesions express high levels of ER $\alpha$, and ER $\alpha$-expressing breast cancer cells are hormone dependent and undergo regression when estrogen is removed [7]. Thus ER $\alpha$ is a well-established predictive marker of hormone sensitivity in breast cancer as well as a positive prognostic marker. In addition to being involved in the initial malignant transformation, the ER may also represent a rationale therapeutic target in canine mammary gland neoplasms, as in breast cancer of women [8]. In a study on immunohistochemical detection of ER $\alpha$ in a canine mammary tumor [4], it was reported that $\mathrm{ER} \alpha$ immunostaining was localized in the nuclei of normal, benign, and malignant epithelial and also in myoepithelial cells, whereas the normal and neoplastic stromal cells, cartilaginous cells, and bone cells in mixed neoplasms were negative.

Martín De las Mulas and coworkers [9] studied the immunohistochemical detection of ER $\beta$ in normal and tumor-affected canine mammary glands. They reported the expression of ER $\beta$ in the nuclei of acinar and ductal epithelial cells and some basal myoepithelial cells. Myoepithelial cells of the complex and mixed tumors, chondrocytes of mixed tumors, and sarcoma cells were negative. Benign mixed and complex neoplasms had a higher expression of the ER $\beta$ than simple neoplasms, suggesting that ER $\beta$ expression may be a favorable prognostic factor because the grade of malignancy of complex carcinomas is lower than that of simple carcinomas. However, the data with regard to ER $\beta$ expression in invasive neoplasms of the human breast and its relationship to prognosis are somewhat contradictory, with some groups reporting that the presence of this receptor is a good prognostic factor and others reporting the reverse. Therefore, the role played by ER $\beta$ in mammary neoplasms is not clear. It was suggested that $\mathrm{ER} \alpha$ and $\operatorname{ER} \beta$ play different roles in cell proliferation and carcinogenesis of breast cancer, partly by mediating the transcription of various genes via different types of deoxyribonucleic acid enhancers. Experimental studies indicated that ER $\beta$ may modulate ER $\alpha$ transcriptional activity. Therefore, ER $\beta$ determination may provide additional information on the responsiveness of canine mammary carcinomas to different endocrine treatments. Considering these factors, it was suggested that the ratio between $\mathrm{ER} \alpha$ and $\mathrm{ER} \beta$ expression in canine mammary neoplasms may be useful to identify subgroups of ER-positive neoplasms [9].

Progesterone is essential for the development and growth of the mammary glands, but it also increases the risk of development of mammary neoplasia. Mechanisms involved in progesterone-induced mammary gland neoplasms include an upregulation of growth hormone $(\mathrm{GH})$ production within the mammary gland [8]. Progesterone receptor (PR) status is a marker for hormone responsiveness and disease prognosis in breast cancer. PR-negative neoplasms generally have poor prognosis than progesterone receptor-positive neoplasms [10]. Positive PR staining has been reported in the nucleus of normal and neoplastic epithelial cells as well as in myoepithelial cells of normal and neoplastic canine mammary tissues. In addition, cytoplasm of the spindle as well as stellate cells of complex and mixed tumors was also reported to be immunoreactive to PR [3].

ER $\alpha$ and PR receptors are present in more than 50\% of mammary neoplasms in dogs [4]. In addition to their ability to predict the response to hormonal therapy, ER and PR status also aids in differentiation of the neoplasm, thereby aiding assessment of patient prognosis [3].

The aim of the present study was to immunohistochemically detect the presence of $\mathrm{ER} \alpha, \mathrm{ER} \beta$, and PR receptors in benign and malignant canine mammary tumors and also identify the association between these markers.

\section{Materials and Methods}

2.1. Tissue Samples. Mammary tumor samples (29 numbers) were obtained by excisional biopsy (mastectomy or nodulectomy) from dogs presented at the teaching hospital of Rajiv Gandhi College of Veterinary and Animal Sciences, (RAGACOVAS), veterinary dispensaries, and other private veterinary practitioners in and around Puducherry, south India. After detailed gross examination, representative tissue samples were fixed in 10\% neutral-buffered formalin [11].

2.2. Histopathology. The tissue samples fixed in $10 \%$ neutralbuffered formalin were processed for histopathological examination by routine paraffin-embedding technique and microtomy [11]. Five-micron thick sections were stained by haematoxylin and eosin method [11], and the tumors were classified according to the WHO histological classification of canine mammary neoplasms [12].

2.3. Immunohistochemistry (IHC). Immunohistochemical detection of $\mathrm{ER} \alpha, \mathrm{ER} \beta$, and PR was performed on 29 formalin-fixed, paraffin-embedded tissue samples representing both benign and malignant neoplasms. IHC assays were performed on $4-\mu \mathrm{m}$ sections of formalin-fixed, paraffinembedded tissue samples. The ready-to-use monoclonal mouse anti-human ER $\alpha$ clone 1D5 (Biogenex, USA) and the polyclonal ready-to-use mouse anti-human ER $\beta$ (Biogenex, USA) were used with a Super Sensitive PolymerHRP Detection System (BioGenex, USA). Dewaxed and rehydrated sections were subjected to heat antigen retrieval by microwaving in $0.01 \mathrm{M}$ citrate buffer, $\mathrm{pH} 6.0$ for 30 minutes at $640 \mathrm{~W}$ ( $80 \%$ power). The ready-to-use mouse anti-human PR Clone PR88 (Biogenex, USA) was used with the Super Sensitive Polymer-HRP Detection System (BioGenex, USA). Dewaxed and rehydrated sections were subjected to heat antigen retrieval by microwaving in citrate buffer $0.01 \mathrm{M}, \mathrm{pH} 6.0$ for 10 minutes at $800 \mathrm{~W}$ plus two periods of 10 minutes at $320 \mathrm{~W}$. All further IHC-staining procedures were carried out according to the instructions in the test kits. Tissue sections were counterstained with Mayer's hematoxylin. Formalin-fixed, paraffin-embedded 
TABLE 1: Immunostaining percentage (\%) and staining intensity (I) of ER $\alpha, E R \beta$, and PR in different canine mammary tumors.

\begin{tabular}{|c|c|c|c|c|}
\hline S1.No. & Tumor type & $\mathrm{ER} \alpha \%(\mathrm{I})$ & $\mathrm{ER} \beta \%(\mathrm{I})$ & PR\% (I) \\
\hline 1 & Papillary cystadenoma & Negative & $10.7(+)$ & Negative \\
\hline 2 & Fibrocystadenoma & Negative & $33.6(+)$ & $44.4(++)$ \\
\hline 3 & Duct papilloma & Negative & $57.2(++)$ & $18.5(+)$ \\
\hline 4 & Fibroadenoma & Negative & $47.1(+++)$ & Negative \\
\hline 5 & Fibroadenoma & Negative & $36.1(++)$ & $51.4(++)$ \\
\hline 6 & Mixed mammary tumor & Negative & Negative & $53.5(+++)$ \\
\hline 7 & Mixed mammary tumor & Negative & $25.2(+)$ & Negative \\
\hline 8 & Mixed mammary tumor & Negative & $36.8(++)$ & $51.9(+++)$ \\
\hline 9 & Mixed mammary tumor & Negative & Negative & Negative \\
\hline 10 & Mixed mammary tumor & Negative & $57.6(++)$ & $60.2(+++)$ \\
\hline 11 & Mixed mammary tumor & Negative & $79.6(+++)$ & Negative \\
\hline 12 & Papillary adenocarcinoma & Negative & $10.5(++)$ & Negative \\
\hline 13 & Papillary adenocarcinoma & Negative & Negative & $61.9(+++)$ \\
\hline 14 & Papillary cystadenocarcinoma & Negative & Negative & Negative \\
\hline 15 & Papillary cystadenocarcinoma & Negative & $15.9(++)$ & $60.5(+)$ \\
\hline 16 & Papillary cystadenocarcinoma & Negative & Negative & $46.4(++)$ \\
\hline 17 & Papillary cystadenocarcinoma & Negative & $11.3(++)$ & Negative \\
\hline 18 & Papillary cystadenocarcinoma & Negative & $11.1(+)$ & $72.5(+++)$ \\
\hline 19 & Solid adenocarcinoma & Negative & $48.5(++)$ & $17(++)$ \\
\hline 20 & Solid adenocarcinoma & Negative & $26(+)$ & Negative \\
\hline 21 & Solid adenocarcinoma & Negative & $77.3(+++)$ & Negative \\
\hline 22 & Complex adenocarcinoma & Negative & $29.2(+)$ & Negative \\
\hline 23 & Complex adenocarcinoma & Negative & $94.7(++)$ & Negative \\
\hline 24 & Complex adenocarcinoma & Negative & $29.2(+)$ & $32.3(++)$ \\
\hline 25 & Carcinosarcoma & Negative & $16.1(++)$ & Negative \\
\hline 26 & Carcinosarcoma & $15.96(+++)$ & $91.1(+++)$ & Negative \\
\hline 27 & Sebaceous adenocarcinoma & Negative & Negative & $19.4(+++)$ \\
\hline 28 & Squamous cell carcinoma & Negative & $33.2(+)$ & $43.5(+++)$ \\
\hline 29 & Hemangiopericytoma & Negative & $99(+++)$ & $35.8(+++)$ \\
\hline
\end{tabular}

tissue sections of canine uterus and human breast cancer were run as positive controls in the standardization of the techniques. The substitution of the specific primary antibodies by Tris-buffered saline (TBS) in tissue sections served as negative control. Classification of staining data was executed semiquantitatively by examining the entire tumor present in the tissue section using immunoperoxidase scoring pattern. The percentage of tumor cells with positive staining (proportional score) was recorded. The intensity of immunohistochemical staining (intensity score) was scored as mild $(+)$, moderate $(++)$, and abundant $(+++)$.

2.4. Statistical Analysis. The immunohistochemical data of each parameter was compared using Mann-Whitney U test. Chi-square test $(\chi 2)$ was applied to study the association between $\mathrm{ER} \alpha, \mathrm{ER} \beta$, and $\mathrm{PR}$ expression in benign and malignant tumors. For all the statistical analyses, the level of critical significance was $P<0.05$ [13].

\section{Results}

3.1. Histopathology. Based on histopathological findings, the tumors were categorised as benign (11 cases) and malignant
(18 cases). The benign tumors were adenoma (2), duct papilloma (1), fibroadenoma (2), and benign mixed tumor (6). The malignant tumors were papillary adenocarcinoma (2), papillary cystadenocarcinoma (5), solid adenocarcinoma (3), complex adenocarcinoma (3), carcinosarcoma (2), sebaceous adenocarcinoma (1), squamous cell carcinoma (1), and hemangiopericytoma (1).

3.2. Immunohistochemistry. In the positive controls, localization of $\operatorname{ER} \alpha, \operatorname{ER} \beta$, and $\mathrm{PR}$ was restricted to the nucleus of cells in all cases of positivity (surface and glandular epithelial cells, stromal fibroblasts of the endometrium, smooth muscle cells of the myometrium, and human breast carcinoma cells). In the negative controls, all nuclei were negative. Immunostaining patterns of $\operatorname{ER} \alpha, \operatorname{ER} \beta$ and $\mathrm{PR}$ in various benign and malignant mammary tumors are represented in Table 1.

3.3. ER $\alpha$ Staining. $E R \alpha$ staining was observed as a brown nuclear staining in the tumor tissue sections. Out of 29 samples analyzed, only one case of carcinosarcoma showed strong positive signals for $\mathrm{ER} \alpha$, in the nuclei of both 
proliferating myoepithelial and epithelial cells (Figure 1). All the other neoplasms (benign and malignant) were negative.

3.4. ER $\beta$ Staining. Out of 29 samples analyzed for ER $\beta$ immunostaining, 23 cases (79\%) expressed positive signals. Strong nuclear (Figure 2) and weak cytoplasmic staining were observed in glandular and ductular epithelial cells. The vascular endothelium and smooth muscles lining the blood vessels also gave strong signals (Figure 3 ). ER $\beta$-staining intensity was abundant in $17 \%$, moderate in $34 \%$, and mild in $28 \%$ of the cases.

Immunoexpression of $E R \beta$ in case of benign tumors was $82 \%(9 / 11)$, and in malignant tumors it was $78 \%(14 / 18)$. Among the benign tumors, duct papilloma had the highest ER $\beta$ expression, and among the malignant tumors the maximum expression was noticed in a case of hemangiopericytoma. There was no significant difference $(P>0.05)$ in ER $\beta$ expression between benign and malignant tumors.

3.5. PR Staining. Out of 29 samples subjected for PR immunostaining, 15 cases (52\%) showed positive signals in the nuclei of neoplastic alveolar and ductal epithelial cells (Figure 4). Very few stromal cells expressed positive immunosignals for PR. Distribution of PR- staining intensity in mammary tumors indicated that $28 \%$ of the tumors expressed abundant intensity $(+++)$ followed by $17 \%$ of moderate $(++)$ and $7 \%$ of mild $(+)$ type.

Out of the 15 PR positive cases, 6 (55\%) were of benign type, and $9(50 \%)$ were of malignant type. Among the benign tumors, the highest expression was noticed in benign mixed tumor, and, among the malignant tumors, papillary adenocarcinoma expressed the maximum immunostaining. There was no significant difference $(P>0.05)$ in PR expression between benign and malignant tumors.

3.6. Combined Expression of Steroid Receptors. Expression of $\mathrm{ER} \alpha$ was noticed only in a solitary case of carcinosarcoma, but it was negative for PR. In both benign and malignant tumors, PR and ER $\beta$ expression was noticed. The most frequent combination recorded in benign tumors was ER $\beta+$ $\mathrm{PR}+$, whereas it was ER $\beta+\mathrm{PR}-$ in malignant tumors. Chi square $(\chi 2)$ analysis revealed no significant association between the distribution of ER $\alpha$ and PR with tumor type (benign or malignant). The combined expressions of ER $\alpha$, $\mathrm{PR}$, and $\mathrm{ER} \beta, \mathrm{PR}$ in canine benign and malignant mammary tumors are represented in Tables 2 and 3, respectively.

3.7. Association of ER $\beta$ with ER $\alpha$ and PR Status in Benign and Malignant Tumors. The associated expression of ER $\beta$ with $\mathrm{ER} \alpha$ and $\mathrm{PR}$ is represented in Tables 4 and 5, respectively.

The most common receptor expression in benign tumors was $\mathrm{ER} \alpha-/ \mathrm{PR}+/ \mathrm{ER} \beta+$ combination and in malignant tumors it was $\mathrm{ER} \alpha-/ \mathrm{PR}-/ \mathrm{ER} \beta+$ combination. Chi square $(\chi 2)$ analysis indicated no significant association between these receptor combinations.

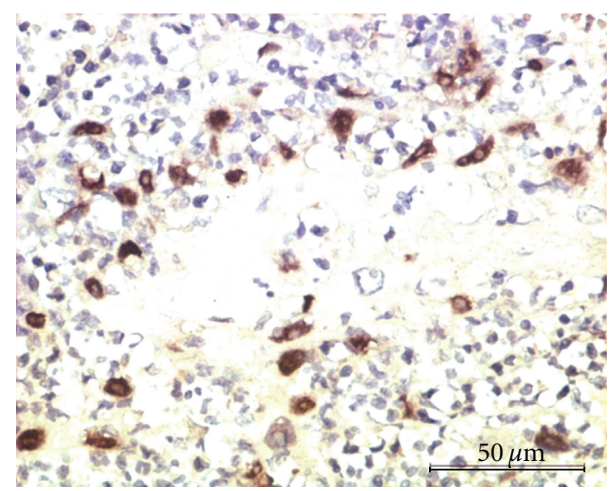

Figure 1: Carcinosarcoma showing the expression of ER $\alpha$ in the nuclei of epithelial and myoepithelial cells. Immunoperoxidase/DAB substrate/Mayer's haematoxylin counterstain $\mathrm{x} 400$.

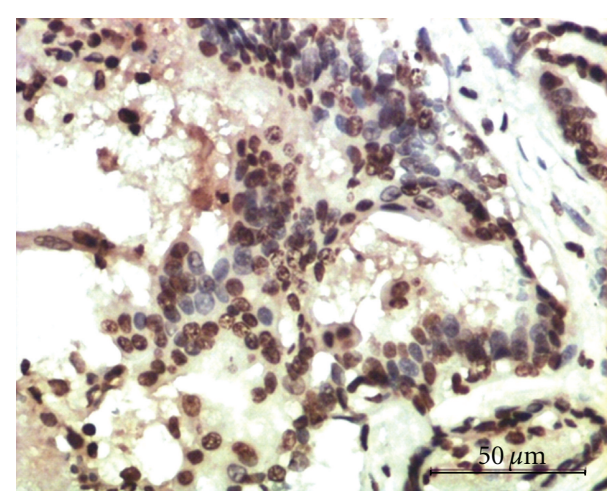

FIGURE 2: Mixed mammary tumor showing strong expression of $\mathrm{ER} \beta$ in the nuclei of epithelial cells. Immunoperoxidase/DAB substrate/Mayer's haematoxylin counterstain x400.

\section{Discussion}

Mammary gland tumors account for more than $50 \%$ of all tumors in the female dog [1]. About $65 \%$ of mammary tumors in dogs are benign mixed tumors, and $25 \%$ are carcinomas. Steroid hormones have been reported to play a key role in the development of mammary neoplasms [8].

The role of ovarian hormones has been well established in human breast cancer studies [14]. In dogs and cats, the involvement of steroid hormones in the development of mammary carcinomas is supported by the protective effects of ovariectomy. Intact females have four times greater risk of getting mammary tumors than the neutered females [15]. Although steroid hormone receptors have been described in canine and feline mammary tumors 25 years ago [1], studies on the role of steroid hormone receptors in the development of mammary tumors in these species are scarce. Progesterone and estrogen receptors are present in both normal and neoplastic tissues. Ninety-five percent of normal canine mammary tissues contain progesterone and/or estrogen receptors. Over $50 \%$ of canine mammary tumors express estrogen and progesterone receptors [16].

Progesterone and estrogen have a crucial role in the control of mammary gland proliferation and tumor formation. 
TABLE 2: Distribution of ER $\alpha$ and PR in benign and malignant mammary tumors.

\begin{tabular}{lllllr}
\hline \multirow{2}{*}{ Tumor type } & $\mathrm{ER} \alpha+$ & $\mathrm{ER} \alpha+$ & $\mathrm{ER} \alpha-$ & $\mathrm{ER} \alpha-$ & Total \\
& $\mathrm{PR}+$ & $\mathrm{PR}-$ & $\mathrm{PR}+$ & $\mathrm{PR}-$ & 11 \\
\hline Benign & - & - & $6(54.55 \%)$ & $5(45.45 \%)$ & 18 \\
Malignant & - & $1(5.56 \%)$ & $9(50 \%)$ & $8(44.44 \%)$ & 29 \\
\hline Total & 0 & 1 & 15 & 13 & 13 \\
\hline
\end{tabular}

TABLE 3: Distribution of ER $\beta$ and PR in benign and malignant mammary tumors.

\begin{tabular}{lllllr}
\hline \multirow{2}{*}{ Tumor type } & ER $\beta+$ & ER $\beta+$ & ER $\beta-$ & ER $\beta-$ & Total \\
& PR+ & PR- & PR+ & $1(9.09 \%)$ & 11 \\
\hline Benign & $5(45.45 \%)$ & $4(36.36 \%)$ & $1(9.09 \%)$ & $1(5.56 \%)$ & 18 \\
Malignant & $6(33.33 \%)$ & $8(44.44 \%)$ & $3(16.67 \%)$ & 2 & 29 \\
\hline Total & 11 & 12 & 4 & 2 & 2 \\
\hline
\end{tabular}

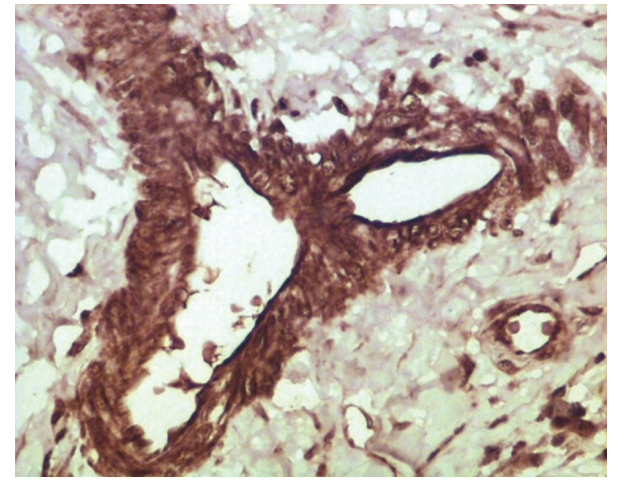

FIGURE 3: Fibrocystadenoma showing ER $\beta$-abundant expression in the endothelium and smooth muscles lining the blood vessels. Immunoperoxidase/DAB substrate/Mayer's haematoxylin counterstain $\mathrm{x} 400$.

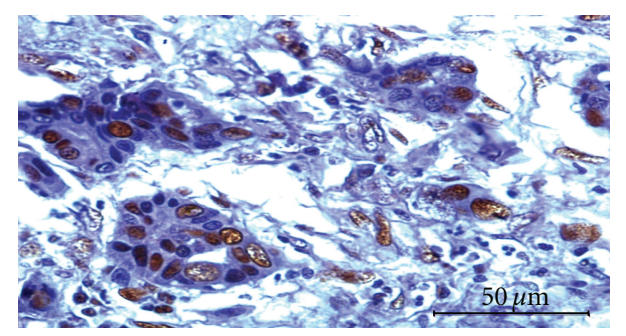

FIGURe 4: Fibroadenoma showing PR expression in the nuclei of epithelial and stromal cells. Immunoperoxidase/DAB substrate/ Mayer's haematoxylin counterstain x400.

In dogs, prolonged exposure of the bitch to progesterone stimulates proliferation of the mammary epithelium. The physiological effect of these hormones is mediated mainly by receptors expressed in the mammary tissue [16]. The estrogen receptor (ER) is a regulator of mammary epithelial growth, proliferation, and differentiation whose complex cellular interactions are mediated by a multitude of ligands, cofactors, and other stimuli. ER is important for normal breast development and function but also plays a role in the development and progression of breast cancer. In the clinical setting, breast cancer patients with an ER-positive status have the greatest likelihood of responding to endocrine therapies [17]. In 1996, the existence of a second related ER subtype, ER $\beta$, was reported [18]. ER $\alpha$ and $\operatorname{ER} \beta$ genes are present on different chromosomes with the greatest homology (close to 100\%) in their DNA-binding domains [19]. The results of some studies have suggested that ER $\alpha$ and $\operatorname{ER} \beta$ are coexpressed in most breast cancers, but there is evidence that a more complex relationship between these two molecules exists [20]. Recent data have indicated that ER $\beta$ expression is higher in premalignant than in invasive disease and is higher in lobular compared with ductal carcinomas in humans [21]. Further evidence suggests that loss of ER $\beta$ expression correlates with increased tumor aggressiveness in breast cancers [14]. Estrogens are known to bind $\operatorname{ER} \beta$ with affinity similar to $\mathrm{ER} \alpha$, and the transcriptional activation via the estrogen response element (ERE) is identical for both receptor forms. ER $\alpha$ and $\operatorname{ER} \beta$ can also form biologically functional receptor heterodimers in tissues in which they are coexpressed.

In the present study, the expression of estrogen (ER $\alpha$, $\mathrm{ER} \beta$ ) and progesterone receptors were studied in canine mammary tumor tissue sections using immunohistochemistry. The expression of ER $\alpha$ was observed only in a solitary case of carcinosarcoma, and all the other 28 neoplasms (benign/malignant) were negative. In earlier studies on canine mammary tumors, a significantly higher expression of $\mathrm{ER} \alpha$ was recorded in benign tumors compared to malignant tumors $[4,5]$.

In the literature, there are very few reports available on the activity and expression of ER $\beta$ in canine mammary neoplasms $[9,22]$. In the present study, $\operatorname{ER} \beta$ expression was observed in both benign and malignant mammary tumors. Immunoreactive products to ER $\beta$ were found markedly in the nuclei of glandular epithelial-type cells. Occasionally, a faint cytoplasmic staining of the glandular epithelial cells was also observed. No immunoreactivity was noticed in the myoepithelial-type cells of complex and mixed tumors, chondrocytes of mixed tumors which was in agreement with an earlier report [9]. Immunoexpression of ER $\beta$ in case of benign tumors was $82 \%(9 / 11)$, and in malignant tumors it 
TABLE 4: Association of ER $\beta$ with ER $\alpha$ and PR status in benign tumors $(n=11)$.

\begin{tabular}{|c|c|c|c|}
\hline & ER $\beta$ negative $\%$ & ER $\beta$ positive $\%$ & $P$ value \\
\hline \multicolumn{4}{|l|}{$\mathrm{ER} \alpha$} \\
\hline Negative (\%) & $2(18 \%)$ & $9(82 \%)$ & - \\
\hline Positive (\%) & 0 & 0 & \\
\hline \multicolumn{4}{|l|}{$\mathrm{PR}$} \\
\hline Negative (\%) & $1(9 \%)$ & $4(36 \%)$ & $>0.05$ \\
\hline Positive (\%) & $1(9 \%)$ & $5(46 \%)$ & \\
\hline
\end{tabular}

TABle 5: Association of $\mathrm{ER} \beta$ with $\mathrm{ER} \alpha$ and PR status in malignant tumors $(n=18)$.

\begin{tabular}{|c|c|c|c|}
\hline & ER $\beta$ negative $\%$ & ER $\beta$ positive $\%$ & $P$ value \\
\hline \multicolumn{4}{|l|}{$\mathrm{ER} \alpha$} \\
\hline Negative (\%) & $4(22 \%)$ & $13(72 \%)$ & $>0.05$ \\
\hline Positive (\%) & 0 & $1(6 \%)$ & \\
\hline \multicolumn{4}{|l|}{$\mathrm{PR}$} \\
\hline Negative (\%) & $1(6 \%)$ & $8(44 \%)$ & $>0.05$ \\
\hline Positive (\%) & $3(17 \%)$ & $6(33 \%)$ & \\
\hline
\end{tabular}

was $78 \%(14 / 18) . \mathrm{ER} \beta$ expression in case of benign tumors was highest in duct papilloma. The maximum immunostaining among the malignant tumors was noticed in a solitary case of hemangiopericytoma. A higher expression of ER $\beta$ in benign tumors compared to malignant tumors has been reported in dogs [9].

In the present study, PR was expressed in the nuclei of epithelial cells in both benign and malignant tumors, whereas the cartilage and bone cells were negative which concorded with an earlier report [23].

The present study also revealed that there was no significant difference in PR expression between benign and malignant tumors. This finding was in contradiction to an earlier report [16] wherein they reported that there was a significant difference in the PR expression between benign and malignant mammary tumors. This discrepancy could be attributed to the less number of mammary tumor cases analyzed in the present study.

Analyses of classical ER and PR have become accepted and useful tools in the prognosis and prediction of hormonal therapy response in human breast cancer [7]. ER $\alpha$ and $\mathrm{PR}$ receptors are present in more than $50 \%$ of mammary neoplasms in dogs [4]. In addition to the ability to predict the response to hormonal therapy, ER and PR status also aids in differentiation of the neoplasm, thereby aiding assessment of patient prognosis [3].

In the present study, the most frequent hormone receptor combination observed was $\mathrm{ER} \alpha-/ \mathrm{PR}+$ combination in $54.55 \%$ of benign and $50 \%$ of the malignant tumors. However, $44.44 \%$ of the malignant tumors were negative for both $\mathrm{ER} \alpha$ and $\mathrm{PR}$ receptor expression. A study reported that the most frequent hormone receptor combination in benign neoplasms was $\mathrm{ER} \alpha+\mathrm{PR}+$ group and $\mathrm{ER} \alpha-\mathrm{PR}+$ among the malignant ones [3].

With respect to $\mathrm{ER} \beta$ and $\mathrm{PR}$, the most frequent hormone receptor combination in the present study among benign tumors was $\mathrm{ER} \beta+/ \mathrm{PR}+$ group $(45.45 \%)$ and among the malignant neoplasms ER $\beta+/ P R$ - group (44.44\%). There are no comparative studies in canine mammary neoplasms on the status of ER $\beta$ with PR expression; however, human breast cancer studies have recorded a higher expression of $\operatorname{ER} \beta$ with PR in malignant cases [14].

In the present study, the association of $\mathrm{ER} \alpha$ and $\mathrm{PR}$ with ER $\beta$ was assessed. The most common hormone receptor combination observed was $\mathrm{ER} \alpha-/ \mathrm{PR}+/ \mathrm{ER} \beta+$ combination $(46 \%)$ in benign tumors and $\mathrm{ER} \alpha-/ \mathrm{PR}-/ \mathrm{ER} \beta+$ combination $(38 \%)$ in malignant tumors. Although there was no significant association between $\mathrm{ER} \alpha$ and $\mathrm{PR}$ with $\mathrm{ER} \beta$ in both benign and malignant tumors, these findings indicated that $\mathrm{ER} \beta$ was consistently expressed irrespective of the $\mathrm{ER} \alpha$ and PR status. There are no comparative studies in canine mammary tumors on the association of $\mathrm{ER} \alpha$ and PR with $\mathrm{ER} \beta$ status. Coexpression of $\mathrm{ER} \beta$ with $\mathrm{ER} \alpha$ and $\mathrm{PR}$, as well as its association with the other indicators of low biological aggressiveness of breast cancer indicated that ER $\beta$-positive tumors were likely to respond to hormonal therapy [14].

Canine mammary tumors are challenging for both clinicians and pathologists because the tumors are difficult to fully characterize; thus, their behaviour and prognosis are difficult to predict. However, prognosis and therapy of mammary tumors can be done based on the hormonal receptor expression profiles of the neoplasm as has been practiced in human breast cancer studies. Tumors which are positive for either $\mathrm{ER}(\mathrm{ER} \alpha / \mathrm{ER} \beta)$ or $\mathrm{PR}$ or both, have a better prognosis than those that are negative for both the receptors. Prognostic power, feasibility, economy, reproducibility, and, if possible, its applicability without highly sophisticated equipments should determine the introduction of new diagnostic methods in clinical oncology.

\section{Acknowledgments}

The authors are thankful to the Dean, RAGACOVAS, Puducherry for providing all the facilities for the conduct of 
the study. The authors thankfully acknowledge the help rendered by the staff of the Department of Veterinary Surgery and Radiology, RAGACOVS, Puducherry and other private veterinarians who helped in the collection of tissue samples for this study.

\section{References}

[1] D. E. Bostock, "Canine and feline mammary neoplasms," British Veterinary Journal, vol. 142, no. 6, pp. 506-515, 1986.

[2] E. Hellmén, "Complex mammary tumours in the female dog: a review," Journal of Dairy Research, vol. 72, special issue, pp. 90-97, 2005.

[3] J. Martín De Las Mulas, Y. Millán, and R. Dios, "A prospective analysis of immunohistochemically determined estrogen receptor $\alpha$ and progesterone receptor expression and host and tumor factors as predictors of disease-free period in mammary tumors of the dog," Veterinary Pathology, vol. 42, no. 2, pp. 200-212, 2005.

[4] A. Nieto, L. Peña, M. D. Pérez-Alenza, M. A. Sánchez, J. M. Flores, and M. Castaño, "Immunohistologic detection of estrogen receptor alpha in canine mammary tumors: clinical and pathologic associations and prognostic significance," Veterinary Pathology, vol. 37, no. 3, pp. 239-247, 2000.

[5] F. Millanta, M. Calandrella, G. Bari, M. Niccolini, I. Vannozzi, and A. Poli, "Comparison of steroid receptor expression in normal, dysplastic, and neoplastic canine and feline mammary tissues," Research in Veterinary Science, vol. 79, no. 3, pp. 225232, 2005.

[6] R. J. Santen, W. Yue, and J. P. Wang, "Potential mechanisms whereby estrogens induce breast cancer in women," Breast Cancer Research, vol. 7, supplement 2, S.08, 2005.

[7] S. A. W. Fuqua, "The role of estrogen receptors in breast cancer metastasis," Journal of Mammary Gland Biology and Neoplasia, vol. 6, no. 4, pp. 407-417, 2001.

[8] K. Sorenmo, "Canine mammary gland tumors," Veterinary Clinics of North America-Small Animal Practice, vol. 33, no. 3, pp. 573-596, 2003.

[9] J. Martín De Las Mulas, J. Ordás, M. Y. Millán et al., “Immunohistochemical expression of estrogen receptor $\beta$ in normal and tumoral canine mammary glands," Veterinary Pathology, vol. 41, no. 3, pp. 269-272, 2004.

[10] D. M. W. Cork, T. W. J. Lennard, and A. J. Tyson-Capper, "Alternative splicing and the progesterone receptor in breast cancer," Breast Cancer Research, vol. 10, no. 3, p. 207, 2008.

[11] L. G. Luna, Ed., Manual of Histologic Staining Methods of the Armed Forces Institute of Pathology, McGraw Hill, New York, NY, USA, 1968.

[12] J. F. Hampe and W. Misdorp, "Tumours and dysplasias of the mammary gland," Bulletin of the World Health Organization, vol. 50, no. 1-2, pp. 111-133, 1974.

[13] J. Fowler and L. Cohen John, Eds., Practical Statistics for Field Biology, Wiley \& Sons, UK, 1990.

[14] T. A. H. Jarvinen, M. Pelto-Huikko, K. Holli, and J. Isola, "Estrogen receptor $\beta$ is coexpressed with $\mathrm{ER} \alpha$ and $\mathrm{PR}$ and associated with nodal status, grade, and proliferation rate in breast cancer," American Journal of Pathology, vol. 156, no. 1, pp. 29-35, 2000.

[15] J. E. Moulton, “Tumors of the mammary gland," in Tumors of Domestic Animals, J. E. Moulton, Ed., pp. 518-552, University of California Press, Berkley, Calif, USA, 3rd edition, 1990.

[16] J. Thuróczy, G. J. K. Reisvaag, E. Perge, A. Tibold, J. Szilágyi, and L. Balogh, "Immunohistochemical detection of progesterone and cellular proliferation in canine mammary tumours," Journal of Comparative Pathology, vol. 137, no. 2-3, pp. 122-129, 2007.

[17] L. K. Diaz and N. Sneige, "Estrogen receptor analysis for breast cancer: current issues and keys to increasing testing accuracy," Advances in Anatomic Pathology, vol. 12, no. 1, pp. 10-19, 2005.

[18] G. G. J. M. Kuiper, E. Enmark, M. Pelto-Huikko, S. Nilsson, and J. A. Gustafsson, "Cloning of a novel estrogen receptor expressed in rat prostate and ovary," Proceedings of the National Academy of Sciences of the United States of America, vol. 93, no. 12, pp. 5925-5930, 1996.

[19] W. Shao and M. Brown, "Advances in estrogen receptor biology: prospects for improvements in targeted breast cancer therapy," Breast Cancer Research, vol. 6, no. 1, pp. 39-52, 2004.

[20] S. I. Hayashi, H. Eguchi, K. Tanimoto et al., "The expression and function of estrogen receptor $\alpha$ and $\beta$ in human breast cancer and its clinical application," Endocrine-Related Cancer, vol. 10, no. 2, pp. 193-202, 2003.

[21] G. P. Skliris, K. Munot, S. M. Bell et al., "Reduced expression of oestrogen receptor $\beta$ in invasive breast cancer and its reexpression using DNA methyl transferase inhibitors in a cell line model," Journal of Pathology, vol. 201, no. 2, pp. 213-220, 2003.

[22] J. C. Illera, M. D. Pérez-Alenza, A. Nieto et al., "Steroids and receptors in canine mammary cancer," Steroids, vol. 71, no. 7, pp. 541-548, 2006.

[23] M. Geraldes, F. Gärtner, and F. Schmitt, "Immunohistochemical study of hormonal receptors and cell proliferation in normal canine mammary glands and spontaneous mammary tumours," Veterinary Record, vol. 146, no. 14, pp. 403-406, 2000 . 

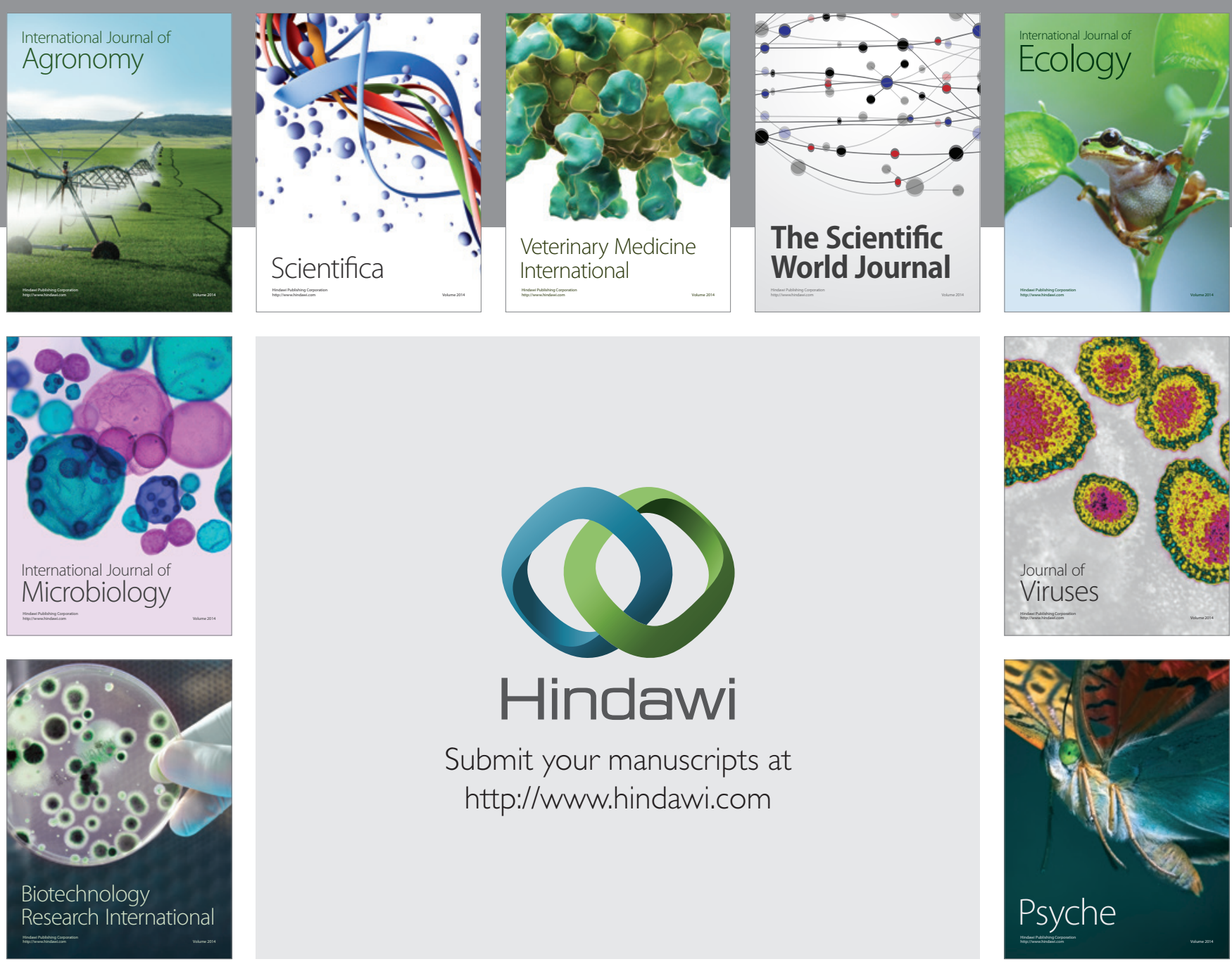

Submit your manuscripts at http://www.hindawi.com
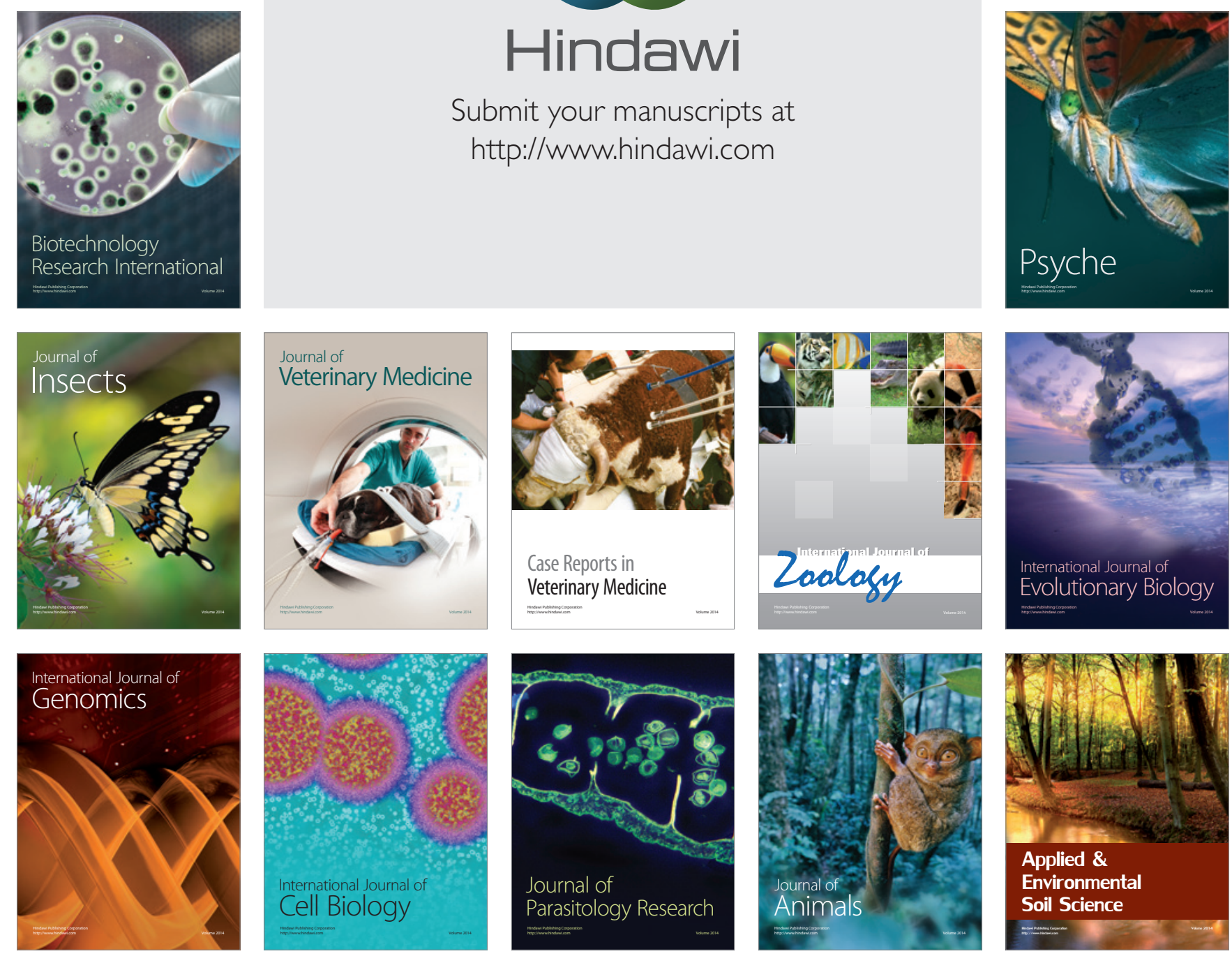